\title{
Effect of Dividend on Stock Price in Emerging Stock Market: A Study on the Listed Private Commercial Banks in DSE
}

\author{
Mohammad Bayezid Ali (Corresponding Author) \\ Department of Finance, Faculty of Business Studies \\ Jagannath University, Dhaka, Bangladesh
}

Tel: 88-017-1502-8151_E-mail: bayezid2001@gmail.com

Tanbir Ahmed Chowdhury, Ph.D

Depaerment of Business Administration, East West University

43-46 Mohakhali C/A, Dhaka-1212, Bangladesh

Tel: 88-011-9913-1645Ｅ-mail: tanbir@ewubd.edu

\begin{abstract}
Stock price reactions to the announcement of dividend of the banking industry of Bangladesh are empirically analyzed. This study examines stock price reactions of listed Private Commercial Banks (PCBs) in Bangladesh surrounding 44 days of the dividend announcement dates. The major objective of this study is to identify whether dividend announcement convey any information to the market that results a price reaction for adjusting the dividend announcement information. The empirical part of this study employs a standard event study methodology to analyze the stock price reaction for dividend announcement. Out of 25 listed sample banks in the observation period, market adjusted stock price declines for 11 banks, rises for 6 banks and no changes for 8 banks and statistical pooled t-test also reveals that stock price reaction to dividend announcement are not statistically significant. Finally, dividend announcement does not convey any information due to strong contribution of the insider trading as well as some other influencing factors in the capital market.
\end{abstract}

Keywords: Dividend, Cumulative Abnormal Return (CAR), Commercial Bank, Free Cash Flow, Price Adjustment Period, Insider Trading

\section{Introduction}

The goal of the corporate entities is to maximize the value of the shareholders' investment in the firm. Managers pursue this goal through their investment, financing and dividend decision. Investment decision involve with the selection of positive net present value projects while financing decision involve with selection of a capital structure that would minimize the cost of capital of the firm (Hamid and Chowdhury, 2005). In addition, managers need to decide dividend decision on a regular basis that involves with whether to payout earnings to shareholders to reduce agency problem (Jensen and Meckling, 1976). However the question remains whether paying out of earnings would essentially create value for the shareholders or not. In this respect, we have found two schools of thought of dividend policy: (1) dividend irrelevance and (2) dividend relevance. Both of the thoughts have conflict with each other and none of them provides complete and satisfactory guidelines. However, both of the schools are trying to establish their thoughts, which led to dividend controversy. A great deal of theoretical and empirical research on dividend effects has been done over the last several decades. This paper is intended to identify the impact of dividend announcement information on the stock prices of 25 DSE listed Private Commercial Banks (PCBs) in Bangladesh in the year 2008.

\subsection{Rationale of the Study}

In any country, capital market is considered to be a very attractive field for any investment. In case of Bangladesh, capital market investment is very important and significant for the development and market capitalization of domestic industry, trade and commerce (Chowdhury, T.A, 2005). However, investors consider several things before they invest their funds in any particular securities. Among them, so far the most important subject matter is return from investment in securities that partly depends on dividend announcement in the stock market. On the other hand, announcement of dividend is considered to be a significant variable for stock price movement. In this paper, we have tried to identify the impact of dividend announcement on stock prices of private commercial banks listed in Dhaka Stock Exchange (DSE). We have taken 25 private commercial banks' stock prices to analyze the impact of dividend announcement. That's why this study is important in a sense that investors in DSE might have an idea about the stock price reaction as a result of dividend announcement in the banking industry and they can use it in 
their investment decision in a more rational and efficient manner. In addition, this study further extends new ways to study the stock market regarding the impact of dividend announcement on stock price.

\subsection{Theoretical Background}

Several theories concerning the relationship of dividend policies and stock returns have been documented in the financial literature (Note: 1) as share price maximization is the central focus in finance. In 1961, Miller and Modigliani (M\&M) advanced the Dividend Irrelevance Theory which theorizes that in a perfect world where there is no corporate and personal taxes, no transaction and floatation costs, no single individual who can affect a security's price through his/ her trade, all individuals have similar expectations with respect to a company's future investment and profit, and where a company has a planned and fixed investment policy (Ross et al. 1999), the value of a company and thus its share prices are unaffected by the distribution of dividends. Hence, the value of a company is determined solely by the earning power and the risk of its assets but not by the manner in which it splits its earnings stream between retained earnings and dividends. They argued that an increase in dividend payment should result in a capital loss to existing shareholders and these two will offset each other. Dividend changes are theorized as involving the tradeoff between the current income and the future selling price. Though, the validity of the perfect world is empirically unjustified, the Dividend Irrelevance Theory is crucial for the formulation of further theories that account for various imperfections in the real world.

One such imperfection which is critical to the development of theories related to dividend is the asymmetric information problem which lends importance to the Signaling Theory. This is also referred to as the information content of dividend hypothesis. According to this theory, also found by M\&M, dividend announcements are hypothesized to have information content, whereby managers use cash dividend announcement to signal changes in their expectation about the future prospect of the company when the markets are imperfect. The information content inherent in a dividend announcement would cause the shareholders to react to the announcement and thus influence the company share prices. There are however debates with respect to the form of information content that is being conveyed to the market through the dividend announcement.

Built on the premise of the information content of dividend hypothesis, other theories have been developed to explain the nature of information content in a dividend announcement. The cash flow signaling theory, also referred as the cash flow hypothesis developed by Bhattacharya $(1979,1980)$, John and Williams (1985) and Miller and Rock (1985), theorized that dividend changes are explicit signals about the current and/or future cash flows, sent intentionally and at some costs by management to the company and its stockholders. Miller and Rock assumed asymmetric information with respect to the magnitude of a company's current internal cash flow, but symmetric information to its level of planned investment and value of assets. They studied the impact of dividend payment. According to them, cash dividend payment is normally associated with a company's operating cash flow assuming the amount of investment and external financing is constant. If a company announced dividend payment which is greater than expected by the market, it reveals an increase of the company's future cash flow which brings up an upward movement in its stock price. The theory thus hypothesized that an increase (decrease) in dividend will lead to an increase (decrease) in stock prices where the levels of cash dividends are associated with the levels of permanent earnings which would affect the stock value.

Jensen (1986), on the other hand, proposed a theory which is widely known as the Free Cash Flow Hypothesis. According to Jensen, the free cash flow exists in a company when there are excess funds left over after taking into account all positive net present value projects. He argues that a conflict of interest between shareholders and managers over the payment policies of these free cash flows could explain the stock price reaction. The theory predicts that stock prices will increase if there is unexpected dividend payment. It associates an increase in dividend with less free cash flow and thus less tendency to over-invest, for example accepting marginal investment projects that have negative NPVs. In other words, changes in dividend payment signal changes in investment policy.

Similar prediction could also be inferred from the agency cost theory forwarded by Easterbrook (1984). According to him, the separation of ownership from control would encourage managers to misuse the company's resources for their personal gain. A regular cash dividend payment ensures the managers are alert with their actions. If there is a reduction in dividend, this would increase access to internally generated funds where there is a likelihood of the management to allocate a greater proportion of the company's resources into perquisites. In such a case, the agency cost theory associates cash dividend decrease with a reduction in a company's equity value, hence a negative price effect is expected out of the announcement.

\subsection{Empirical Evidence}

Numerous empirical studies have been carried out to determine the stock market reactions to dividend announcements. Aharony and Swary (1980), Kwan (1981), Eades (1982), and Woolridge (1982), have found a 
significant positive association between announcement of dividend changes and the stock return, using the dividend announcement made in isolation of other firm news report. Gordon (1962 and 1963) and Walter (1963) support the dividend relevance doctrine. They suggest that dividend policy and investment policy are inter-linked. Investment policy can not be separated from dividend policy and the choice of an appropriate dividend policy affects the value of the firm.

The leading proponents of the bird-in-the-hand theory (Gordon, 1962; and Lintner, 1962) found that stockholder value a dollar received in dividend more highly than dollar earnings retained. Therefore, dividend policy is relevant to the value of shares. Miller and Scholes (1981) have argued that the observed relationship between common stock returns and dividend yields as attributed to the favorable information contained in the knowledge that a firm will actually declare any dividend. Dhillon and Jhonson (1994) examine the stock and bond price reaction to dividend changes. The positive stock market response to dividend increases has several potential explanations, two of the more commonly discussed being information content and wealth redistribution between stockholders and bondholders. The evidence presented by Dhillon and Jhonson (1994) support the wealth redistribution hypothesis but does not rule out the information content hypothesis. Typically, Dhillon and Jhonson (1994) found that the bond price reaction to announcement of large dividend changes is opposite to the stock price reaction. Their result differs from those of Handjinicolaou and Kalay (1984) who analyzed bond returns around dividend changes, and reported that the bond prices are not affected by dividend increases but the bond prices react negatively to divided reductions. Dhillon and Jhonson (1994) argue that their data supports the information content hypothesis. In contrast, Jayaraman and Shastri (1988) find insignificantly negative bond price reactions to dividend announcement.

Black and Scholes (1974) have found that corporations that increase its dividend can expect this will have no definite effect on its stock price. The price may change temporarily in response to a change in the dividend, because the market may believe that the change indicates something about the probable future course of earnings. If it becomes clear that the change was not made because of any change in estimated future earnings; this temporary effects will disappear. Thus a corporation may want to choose its dividend policies under the assumption that changes in dividend policy will have no permanent effect on its stock price.

Other researchers made efforts to further understand the dividend controversy. Among them, Brennan (1970 and 1973), Litzenberger and Ramaswamy (1979 and 1980) showed that it is not optimal for the investors to receive dividends if their marginal tax rate is greater than zero and investors' after-tax expected rate of return (discount rate) depends on the dividend yield and systematic risk. This lead to an idea that at least dividend might have some tax-induced effect on the stock prices. Average investors, subjects to their personal tax rates, would prefer to have less cash dividend if it is taxable: the size of optimal dividend inversely related to personal tax rates (Pye, 1972). Hence stock prices tend to decline after announcement of dividend increase.

The empirical studies however showed mixed evidence, using the data from US, Japan and Singapore markets. A number of studies found that stock price has a significant positive relationship with the dividend payment [Gordon (1959), Ogden (1994), Stevens and Jose (1989), Kato and Loewenstein (1995), Ariff and Finn (1986), and Lee (1995)] while other found a negative relationship [Loughlin (1989), and Eason and Sinclair (1989)]. A negative relationship between dividend announcement stock returns is expected due to tax effect, but researchers tended to relate the positive relationship between stock returns and dividend announcement with the information effect of dividend. The dividend information hypothesis postulates that cash dividend carries information regarding the future cash flows of firm that is to be reflected in the market price of stock after announcement of dividend, particularly when dividend increases [ Bhattacharya (1979), Bar-Yosef and Huffman (1986) and Yoon and Starks (1995)].

Docking, Scott, Koch and Poul (2005) examined the sensitivity of the investor reactions to the recent direction or volatility of underlying market movements. They found that dividend change announcements elicit a greater change in stock price when the nature of the news (good or bad) goes against the grain of the recent market direction during volatile times. For example, announcements to lower dividends elicit a significantly greater decrease in stock price when market returns have been up and more volatile. Similarly, announcements to raise dividends tends to elicit a greater increase in stock price when market returns have been normal or down and more volatile, although this latter tendency lacks statistical significance. We suggest an explanation for these results that combines the implications of a dynamic rational expectations equilibrium model with behavioral considerations that link the responsiveness of investors to market direction and volatility.

Hamid and Chowdhury (2005) used two measures i.e. daily market- adjusted abnormal return (MARR) and daily cumulative abnormal return (CAR) to study the impact of dividend announcement on shareholders' value. They explained MARR as an indicator of the relative daily percentage price change in the dividend paying stocks compared to the change in average market price. Whereas CAR has been defined as a measure of the investors' total 
return over a period starting from well before the announcement of dividend to well after the dividend announcement day. They have taken 137 samples of dividend paying companies listed on Dhaka Stock Exchange and found that MARR on the day of dividend announcement was not statistically significant which entails that the market reacts earlier than the actual announcement of dividend. On the other hand, the findings of CAR results that investors lost more value in the ex-dividend period than the value gained in the pre-dividend period. These findings also suggest that dividend announcement does not carry information about the future earnings and cash flows of the companies.

Hossain. M. (2006) examined the determinants of stock price and return movements of listed companies of Dhaka Stock Exchange (DSE). He used several factors like number of listed securities, number of initial public offerings, earnings per share, dividend per share dividend pay out ratio and also used some macroeconomic variables like gross domestic product (GDP), per capital income, savings, investment, export, import, foreign exchange reserve, inflation rate, money supply, consumption, deposit interest rate, advance interest rate as influential factors for determining the price of stock. He found a negative relation in between dividend yield and the price of any stock.

Rahman, Z. and Rahman, L. (2008) in their study of stock price behavior around ex-dividend date from DSE found an increase of stock prices. They have made a conclusion that ex-dividend price increased instead of dropped in DSE that implies a clear preference for capital gains without having any focus of dividends by the stockholders.

\section{Methodology and Sample}

To examine the impact of the event - "Dividend announcement" - on the stock prices, we analyzed the stock price behavior of the selected private commercial banks surrounding 44 days of the date of dividend announcement of DSE. Given the depth of information available about the stock prices from Dhaka Stock Exchange (DSE), our null hypothesis is that dividend announcement don't have any significant impact on the stock price movement of the banks listed in DSE. Symbolically,

$H_{0}$ : Dividend announcement doesn't contain price sensitive information.

$H_{A}$ : Dividend announcement contain price sensitive information.

\subsection{Sample Selection}

This study covers the impact of dividend announcements on the stock price of all the listed private commercial banks at DSE between January 2008 and September 2008. During our selected sample time frame we found 29 listed private commercial banks at DSE. At the initial stage, we have taken all the listed private commercial banks. Then we have selected banks as our sample banks on the basis of the following two methodological conditions which are (a) The banks which had declared their dividend 30 days after January 1, 2008 and (b) The banks which had announced their record date within September 30, 2008. The above two conditions are highly significant for ensuring stock price data, dividend announcement date and record date are perfectly compatible with the methodology used in this study; to avoid unnecessary complicacy; to get an unbiased result and also for numerous reasons.. However, we are not in a position to incorporate 4 listed private commercial banks within our sample frame for the following reasons: (i) United Commercial Bank Ltd. (UCBL) had announced their record date but that was far away from our sample time frame; (ii) Rupali Bank was imposed restriction by Securities and Exchange Commission (SEC) in trading securities due to major restructuring process in their ownership status which went on within our sample time frame; (iii) ICB Islamic Bank Ltd was found newly established bank having no data about dividend announcement date and record date within our sample time frame; (iv) Brac Bank involves with only 20 days trading data before the dividend announcement date that matches within our sample time frame. But we require 30 days trading information before the dividend announcement date to comply perfectly with the methodological issue explained in earlier. According to these sample selection criteria, finally we have selected 25 out of 29 listed private commercial banks at DSE

Moreover, to capture the only impact of dividend announcements, 25 banks that have price sensitive information around the date of dividend announcements are taken into consideration for this research. In this regard, declaration of rating agency's report, earnings, right share offer, mergers etc were also considered as price sensitive information. We have excluded all the price sensitive information (except dividend announcement date and record date), which Hand et al (1992) refers to as 'contaminated events'.

\subsection{Event Window}

In conducting the event study it is important to identify the period over which the prices of relevant financial instruments will be examined. This period is referred to as 'event window' (Campbell, Lo and Mackinley, 1997). For the purpose of this study, an event window is set equal to 44 days starting from 30 days before the dividend announcement date and ending 14 days after the announcement (Figure: 2). The date of dividend announcement is 
defined as $t=0$, a window of 30 days before the event as 'pre-event window' and a window of 14 days after the event divided equal to two equal parts as 'post- event window'. The date of dividend announcement i.e. $t=0$ has been considered as the date of declaration related to dividend distribution by the respective Board of Directors of the banks.

The 'post-event window' is sub-divided into two intervals: +1 to +7 days price impact after no price limit date after the dividend announcement date defined as 'price adjustment period' and another +1 to +7 days price impact before record date defined as 'market response to the period of availing dividend benefit'. The impact of dividend announcement is tested over two interval of post-event window because not all price reaction are not due to divided announcement, sometimes stock price changes only to avail dividend benefit. The entire price impact could better be materialized in the two intervals (Figure: 1)

\subsection{The Event Study Approach}

The event study methodology is well accepted and has been used in a variety of management research to study the effect on the economic value of firm actions such as e-commerce (Subramani et al. 2001), CEO incentives (Kang et al. 2006), new product introductions (Chaney et al. 1991), earnings press releases (Elaine Henry 2006) etc.

In analyzing the impact of the event - "Dividend announcement" - we intended to use Standard Event Study Technique suggested by Campbell, Lo and MacKinley (1997) that examines abnormal return of the stock prices in the event window. Abnormal returns $\left(A R_{i t}\right)$ are defined as the difference between actual returns and the returns predicted by the market model:

$$
A R_{i t}=R_{i t}-\left(\hat{\alpha}_{i}+\hat{\beta}_{i} R_{m t}\right)
$$

If any information resulting from an event is believed to affect a firm's current and future earnings, its security price changes as soon as the market learns about the event. To examine whether an event had any impact on the firm's values, pre event and post event abnormal returns (ARs) and cumulative abnormal returns (CARs) are measured. Conclusions are drawn on the test results of statistical significance of cumulative abnormal returns (CARs).

But, form of our market efficiency pushes us back in using the standard event study technique. Initially, we followed standard event study model of Campbell, Lo and MacKinley (1997) and developed a market model for determining the predicted returns of a relevant sample. The daily equity price return for the relevant company $\left(\mathrm{R}_{\mathrm{it}}\right)$ was regressed upon the corresponding industry index $\left(\mathrm{R}_{\mathrm{mt}}\right)$ using ordinary least square method. The parameters $\hat{\alpha}, \hat{\beta}$ were estimated over a three month period preceding the event. The benefits of using this model depend on coefficient of determination $\mathrm{R}^{2}$ that measures the strength of linear relationship between two variables. But in most of the cases, it is observed that adjusted $\mathrm{R}^{2}$ between two variables were very low that signifies a very low relationship between the industry index and the individual company price index. As it is known that index comprises both frequently and infrequently traded shares. In addition, it is also known that frequently traded shares cause upward bias and infrequently traded shares cause downward bias. That's why we depart from using this model that calculates abnormal returns to study the impact of the event. We subsequently develop an alternative approach appropriate to our market that avoids regression model but considers the movement of industry index.

\subsection{Alternative Approach: Market Adjusted Returns}

After excluding all the 'contaminated samples' from the primary list, a final size of 25 samples have been constructed. To test the hypothesis, market adjusted equity prices of these samples in the event windows will then be analyzed. Justification for considering market adjusted equity prices $\left(\operatorname{Adj} R_{i t}\right)$ over raw equity prices $\left(R_{i t}\right)$ is to isolate the movement of financial prices in the event window that is not due to factors influencing the industry index. Market adjusted equity prices neutralize the price movement from the movements caused by the industry index ${ }^{1}$. For pre-event window market adjusted price of an equity (i) for a day (t) is calculated as:

$$
\text { Adj } R_{i t}=\frac{R_{i t}}{100+30 \text { day Av. Industry Index Growth }} \times 100
$$

On the other hand, for post-event window (both for 7 days after no price limit date associated with dividend announcement or price adjustment period and 7 days before record date or market response to the period of availing dividend benefit), market adjusted price in the post-event window of an equity (i) for a day (t) (Note 2) is calculated as:

$$
\operatorname{Adj} R_{i t}=\frac{R_{i t}}{100+7 \text { day Av. Industry Index Growth }} \times 100
$$

To examine the hypothesis, aggregate market adjusted equity returns (AR) for a day (t) have then been calculated, summing across the prices of all 25 banks in the event window. 
$\operatorname{Adj} \quad R_{t}\left(A R_{t}\right)=\sum_{i=1}^{25} \operatorname{Adj} \quad R_{i t}$

The market adjusted equity returns behavior for each day are then observed between two windows, pre-event window ( 30 days before the dividend announcement date) and post-event window ( 7 days after no price limit date related to dividend announcement and 7 days before record date), to draw the conclusion.

\section{Testing Hypothesis}

The null hypothesis of this study is that dividend announcement doesn't contain price sensitive information i.e. dividend announcement doesn't have any significant impact on stock prices of the selected banks and our alternative hypothesis remains that dividend announcement significantly affect (upsurge) the stock prices of the selected banking entity. Assuming that prices of both windows are normally distributed and are independent of each other; statistical significance of the hypothesis has been tested using pooled $t$-test at $95 \%$ confidence level. Correlation analysis between adjusted stock return during 30 days before dividend announcement date and 7 days after no price limit date associated with dividend announcement as well as 30 days before dividend announcement date and 7 days before record date will also be conducted to test our hypothesis.

\subsection{Empirical Results}

Impact of dividend announcement on stock prices behavior of 25 selected private commercial banks has been analyzed. Dividend announcement generates a very low significant impact on the stock price movement. The adjusted mean return index of the stocks 30 days before dividend announcement is tk.98.28 whereas the adjusted mean return index in the price adjustment period ( 7 days after the no price limit date related to dividend announcement) is tk.100.09 and 7 days before the recode date is tk.105.25. In this case, stock price increases by $1.84 \%$ in the price adjustment period after the dividend announcement and $7.09 \%$ in the period when investors wishes to avail the dividend benefit ( 7 days before record date). Thus it is evident that dividend announcement has a very less significant impact on stock price changes in the price adjustment period. But a relatively higher rate of increase takes place in 7 days before record date. A list of mean return as well as their standard deviation from 25 private commercial banks during 30 days before dividend announcement date, 7 days after no price limit date and 7 days before record date is given in Table: $1 \& 2$. Figure 2 demonstrates the result (Note: 3 ).

The graph in Figure: 2 reveal the movement of stock prices around the dividend announcement date. Its depicts that, during 30 days before the dividend announcement date, stock price index is lower than average stock price index. Stock price index rises very little (1.84\%) in the next 7 days after the dividend announcement date. In addition, another rise in stock price index $(7.09 \%)$ is found just 7 days before the record date. The first reaction in stock price was actually due to dividend announcement and the later was due to market response to avail the dividend benefit. A break in the curve was due to differences in time lag for different banks between dividend announcement date and record date Based on this curve, we can say that the impact of dividend announcement on stock price is very insignificant in 7 days after the dividend announcement date but a rise in stock price is found 7 days before the record but that is not due to dividend announcement and also less significant to dividend announcement.

On the other hand, individual stock index for different banks shows different reactions to dividend announcement (Figure: 4). Bank Asia, The Premier Bank, Dhaka bank, Trust Bank Shahjalal Islami Bank, IFIC Bank, Social Investment Bank, National Bank, Prime Bank belong to that category where dividend announce results decrease in stock price index immediately 7 days after no price limit date related to dividend announcement.. Mutual Trust Bank, AB Bank, EXIM Bank, One Bank, NCC Bank and Standard Bank are found having stock index less than average index in 30 days before dividend announcement but that moves to average index 7 days after the dividend announcement. Al-Arafah Islami Bank, Jamuna Bank, Pubali Bank, and Uttara Bank shows no price reaction in both pre-event and post-event window. But only three banks (i.e. The City Bank, Mercantile Bank, and South East Bank) show an upward rise in stock index after the dividend announcement date. A rise in stock price index is found in almost every bank during the period of 7 days before the record date and it was the price reaction only to avail the dividend benefit (Note: 4). On an average, this study found no significant price reaction as a result of dividend announcement.

While our study provide evidence that stock price have no significant response to the dividend announcement, statistical significant test also resembles to out result. In case of parametric pooled t-test, p-value is greater than 5\% level of significance providing acceptance to our null hypothesis that dividend announcement doesn't contain price sensitive information. On the other hand, there is a very high degree of association in between stock price during 30 days before dividend announcement date and 7 days after the dividend announcement date (i.e. $r=0.976)($ Table: 3 ) and also the stock price during 7 days before that record date (i.e. $r=0.986$ ). This correlation output also agrees with 
our evidence that dividend announcement have no significant impact on the stock price movement of the selected 25 private commercial banks in Bangladesh.

\section{Conclusion}

A standard event study methodology is used to investigate the effect of dividend announcement on stock price. The findings accept our null hypothesis and provide no strong evidence that stock price reacts significantly on the announcement of dividend. This may be due to insider trade in the market, so, the information used to be adjusted with the stock prices before announcement and consequently the announcement of dividends do not carry any new information to the market. Furthermore insider trading causes asymmetric information in the market and as insiders have private information, so outsiders love to follow the insiders to buy and sell shares. Therefore shareholders are always mislead because of asymmetric information and consequently positive information about dividend also become an ineffective device in the market. As the DSE is still in the speculation and manipulation stage, so speculators play their role in the market for short- term period. However it is notable that insiders, brokers and the exchange employees are the speculators of the market and as these informed speculators play their role in the market for short-term gain that causes dividend information ineffective. As a result announcement of dividend generates no significant impact on the movement of stock prices.

\section{References}

Arahony, J. and I. Swary (1980). "Quarterly Dividend and Earnings Announcements and Stockholders Returns: An Empirical Analysis", Journal of Finance, 35, 1-12.

Abdullah N. H., Rashid R. A. and Ibrahim Y. (2002). "The Effect of Dividend Announcements on Stock Returns for Companies Listed on the Main Board of Kuala Lumpur Stock Exchange”, Malaysian Management Journal, 6, No. 1 $\& 2$.

Ariff, M. and Finn, F.J. (1986). "Announcement Effects and Market Efficiency in a Thin Market: An Empirical Application to the Singapore Equity Market", Asia Pacific Journal of Management, .6, 243-267.

Black, F. and M. S. Scholes, (1974). "The Effect of Dividend Yield and Dividend Policy on Common Stock Prices and Return", Journal of Financial Economics, 1, 1-22.

Brennan, M. J. (1970). "Taxes Market Valuation and Corporate Financial Policy", National Tax Journal, 26, 1115-1121.

Bhattacharya, S, (1979)."Imperfect Information, Dividend Policy, and 'the bird in the hand' Fallacy", The Bell Journal of Economics, 10, No.1, 259-270.

Bar-Yosef, S. and Huffman, L. (1986)."The Information Content of Dividends: A Signaling Approach", Journal of Financial and Quantitative Analysis, 21, No.1.

Chowdhury, T.A.(2005) "Stock Markets Behavior in Bangladesh", Journal of Business Studies, Bangladesh Open University (BOU). 3, no.1\& 2, 47-77.

Dhillon, U., and H. Johnson (1994). "The Effect of Dividend Changes on Stock and Bond Prices", Journal of Finance, 49, 281-289.

Docking, Diane Scott; Koch, Paul D. (2005)." Sensitivity of investor reaction to market direction and volatility: dividend change announcements", Journal of Financial Research, Internet Paper.

Eades, K. (1982). "Empirical Evidence on Dividends as a Signal of Firm Value", Journal of Financial and Quantitative Analysis, 17 471-500.

Easterbrook, F. (1984).”Two Agency Cost Explanations of Dividends", American Economic Review, 74, 650-659.

Gordon, M. J. (1962). "The Savings, Investment and Valuation of the Corporation", Review of Economics and Statistics, 45, 37-51.

Gordon, M. J. (1963). “Optimum Investment and Financing Policy”, Journal of Finance, 18, 264-272.

Handjinicolaon, G., and A. Kalay (1984). "Wealth Redistributions or Changes in Firm Value: An Analysis of Returns to Bondholders and Stockholders Around Dividend Announcements", Journal of Financial Economics, 13, $35-63$.

Jayaraman, N. and K. Shastri (1988). "The Valuation of Specially Designed Dividends", Journal of Financial and Qualitative Analysis, 23, 301-312.

John, K. and Williams, J. (1985). "Dividends, Dilution and Taxes: A Signaling Equilibrium”, Journal of Finance, 40, 1053-1070. 
Jensen, M. (1986)."Agency Cost of Free Cash Flows, Corporate Finance and Takeovers", American Economic Review, 76, 323-329.

Jensen, M. and Meckling, W. (1976). "Theory of Firm: Managerial Behavior, Agency Cost, and Ownership Structure" Journal of Financial Economics, .3, 306-360.

Kato, K. and Loewenstein, U. (1995). “The Ex-Dividend-Day Behavior of stock Prices: The Case of Japan”, The Review of Financial Studies, 8, 816-847.

Kwan, C. (1981)."Efficient Market Tests of the Information Content of Dividend Announcement: Critique and Extension", Journal of Finance and Quantitative Analysis", 16, 193-206.

Lintner, J. (1962).'Dividends, Earnings, Leverage, Stock Prices and The Supply of Capital to Corporations", The Review of Economics and Statistics", 44, 243-269.

Lee, B.S. (1995)."The Response of Stock Prices to Permanent and Temporary Shocks to Dividend", Journal of Financial and Quantitative Analysis, .30, 163-195.

Litzenberger, R.H., and Ramaswamy, K. (1979). "The Effects of Personal Taxes and Dividends on Capital Asset Prices", Journal of Financial Economics, 7, 163-195.

Loughlin P.H. (1982). "The Effects of Dividend Policy on Changes in Stockholders' Wealth", A Ph.D Thesis, Graduate School of Saint Louis University, USA.

Mollah A.S., Mobarek A.and Islam R. (2007). "Market Response to Dividend Increases and Changes in Payout Ratios: An Empirical Investigation on the Dhaka Stock Exchange Listed Textile Sector Companies", Journal of Banking and Financial Services, 1, No. 1 \& 2.

Miller, M., and M. Scholes (1981). "Dividends and Taxes: Empirical Evidence”, CRSP Working Paper, University of Chicago.

Miller, M. and Rock, K. (1985). “Dividend Policy Under Asymmetric Information”, Quarterly Journal of Economics, 95, 1031-1051.

Mosarof, M. (2006). "Empirical Evidence from Determinants of Stock Price and Return of Dhaka Stock Exchange”, Journal of Finance and Banking, 8, 111-124.

Rahman, Z. and Rahman, L. (2008). “ Stock Price Behavior Arounf Ex-dividend Day: Evidence from Dhaka stock Exchange", Journal of Business Administration, 34, 127-144.

Stevens, J.L. and Jose, M.L., (1992).”The Effect of Dividend Payout, Stability, and Smoothing on Firm Value", Journal of Accounting Auditing and Finance, .7, 195-216.

Uddin M. H., and Chowdhury G. M. (2005). "Effect of Dividend Announcement on Shareholders' Value: Evidence from Dhaka Stock Exchange”, Journal of Business Research, Vol.1.

Walter, J. E., (1963). "Dividend Policy: Its Influence on the Value of Enterprise”, Journal of Finance, 18, 280-291.

Woolridge, J.R. (1982).“The Information Content of Dividend Changes”. Journal of Financial Research, 5, 237-247.

Yoon, P.S. and Starks, L.T. (1995). "Signaling, Investment Opportunities, and Dividend Announcements", The Review of Financial Studies, 8, 995-1018.

\section{Notes}

Note 1. Implication of Corporate Finance Theories in Predicting the Sign of Abnormal Returns Associated with Dividend Announcement

\begin{tabular}{|l|l|l|}
\hline Theory & Dividend Announcement & \multicolumn{1}{|c|}{ Expected Price Effect } \\
\hline $\begin{array}{l}\text { Cash Flow Signaling Theory/ Information } \\
\text { Content Hypothesis }\end{array}$ & Increase & Positive price effect \\
\cline { 2 - 3 } & Decrease & $\begin{array}{l}\text { Negative price effect } \\
\text { (signal current and/or future cash flows) }\end{array}$ \\
\hline Jensen's Free Cash Flow Hypothesis & Increase & Positive price effect \\
\cline { 2 - 3 } & Decrease & $\begin{array}{l}\text { Negative price effect } \\
\text { (signal changes in investment policy) }\end{array}$ \\
\hline Agency Cost Theory & Decrease & $\begin{array}{l}\text { Negative price effect } \\
\text { (misuse of funds) }\end{array}$ \\
\hline
\end{tabular}


Note 2. In order to neutralize the price movement, two separate weighted average industry indices for banking industry were developed. For banking industry price index January 1, 2008 were considered as the base price.

Note 3. The graph has been drawn from the market adjusted equity prices, calculated as per methodology, considering the event day $\left(t_{0}\right)$ price as 100 .

Table 1. Mean and Standard Deviation of Pre-event and Post-event Window

\begin{tabular}{|c|c|c|c|c|c|c|c|}
\hline \multirow{2}{*}{$\begin{array}{l}\text { Sl } \\
\text { No }\end{array}$} & \multirow[t]{2}{*}{ Name of the Banks } & \multicolumn{3}{|c|}{$\begin{array}{c}\text { Pre-event Window (30 Days before } \\
\text { Dividend Declaration Date) }\end{array}$} & \multicolumn{3}{|c|}{$\begin{array}{c}\text { Post-event Window (7 days after no } \\
\text { Price Limit Date) }\end{array}$} \\
\hline & & $\mathrm{N}$ & Mean & Std. Deviation & $\mathrm{N}$ & Mean & Std. Deviation \\
\hline 1 & AB Bank & 30 & 2891.24 & 219.25 & 7 & 3274.16 & 86.60 \\
\hline 2 & AL-ARAFAH ISLAMI BANK LTD. & 30 & 396.68 & 8.81 & 7 & 363.47 & 7.72 \\
\hline 3 & BANK ASIA LIMITED & 30 & 519.08 & 18.76 & 7 & 511.59 & 8.32 \\
\hline 4 & DHAKA BANK LIMITED. & 30 & 632.01 & 21.61 & 7 & 585.86 & 8.57 \\
\hline 5 & DUTCH BANGLA BANK LTD. & 30 & 7893.61 & 818.19 & 7 & 11551.43 & 955.07 \\
\hline 6 & EASTERN BANK LIMITED. & 30 & 1024.64 & 13.32 & 7 & 1290.67 & 27.96 \\
\hline 7 & $\begin{array}{l}\text { EXPORT IMPORT BANK OF BD. } \\
\text { LTD. }\end{array}$ & 30 & 377.94 & 8.71 & 7 & 393.67 & 2.64 \\
\hline 8 & IFIC Bank & 30 & 2838.35 & 102.59 & 7 & 2950.29 & 42.48 \\
\hline 9 & $\begin{array}{l}\text { ISLAMI BANK BANGLADESH } \\
\text { LIMITED. }\end{array}$ & 30 & 5869.82 & 155.45 & 7 & 5703.95 & 80.49 \\
\hline 10 & Jamuna Bank Ltd. & 30 & 301.95 & 12.32 & 7 & 294.13 & 7.02 \\
\hline 11 & MERCANTILE BANK LIMITED & 30 & 412.44 & 5.14 & 7 & 414.11 & 4.08 \\
\hline 12 & MUTUAL TRUST BANK LTD. & 30 & 534.08 & 22.37 & 7 & 553.73 & 2.60 \\
\hline 13 & NATIONAL BANK LIMITED. & 30 & 1564.49 & 60.62 & 7 & 1529.12 & 22.56 \\
\hline 14 & NCC Bank & 30 & 446.65 & 10.36 & 7 & 448.06 & 4.73 \\
\hline 15 & ONE BANK LIMITED & 30 & 514.17 & 40.98 & 7 & 489.45 & 18.62 \\
\hline 16 & PRIME BANK LTD. & 30 & 883.48 & 11.22 & 7 & 872.93 & 6.19 \\
\hline 17 & PUBALI BANK LIMITD. & 30 & 845.38 & 19.05 & 7 & 855.01 & 24.96 \\
\hline 18 & SHAHJALAL ISLAMI BANK LTD. & 30 & 354.03 & 6.11 & 7 & 344.53 & 3.14 \\
\hline 19 & SOCIAL INVESTMENT BANK LTD. & 30 & 411.15 & 22.69 & 7 & 345.55 & 3.51 \\
\hline 20 & SOUTHEAST BANK LIMITED. & 30 & 539.76 & 14.26 & 7 & 543.12 & 8.23 \\
\hline 21 & STANDARD BANK LIMITED & 30 & 279.87 & 13.72 & 7 & 291.02 & 1.84 \\
\hline 22 & THE CITY BANK LIMITED. & 30 & 619.75 & 9.85 & 7 & 600.86 & 14.65 \\
\hline 23 & The Premier Bank Ltd. & 30 & 267.31 & 6.95 & 7 & 230.09 & 2.04 \\
\hline 24 & Trust Bank Limited & 30 & 670.96 & 48.04 & 7 & 594.89 & 24.29 \\
\hline 25 & UTTARA BANK LIMITED. & 30 & 4741.55 & 162.97 & 7 & 4628.37 & 50.60 \\
\hline
\end{tabular}


Table 2. Mean and Standard Deviation of Pre-event and Post-event Window

\begin{tabular}{|c|c|c|c|c|c|c|c|}
\hline \multirow{2}{*}{$\begin{array}{c}\text { Sl } \\
\text { No }\end{array}$} & \multirow[t]{2}{*}{ Name of the Banks } & \multicolumn{3}{|c|}{$\begin{array}{l}\text { Pre-event Window (30 Days before } \\
\text { Dividend Declaration Date) }\end{array}$} & \multicolumn{3}{|c|}{$\begin{array}{l}\text { Post-event Window (7 days Before } \\
\text { Record Date) }\end{array}$} \\
\hline & & $\mathrm{N}$ & Mean & Std. Deviation & $\mathrm{N}$ & Mean & Std. Deviation \\
\hline 1 & AB Bank & 30 & 2891.24 & 219.25 & 7 & 3571.18 & 144.53 \\
\hline 2 & AL-ARAFAH ISLAMI BANK LTD. & 30 & 396.68 & 8.81 & 7 & 558.69 & 7.25 \\
\hline 3 & BANK ASIA LIMITED & 30 & 519.08 & 18.76 & 7 & 523.46 & 4.44 \\
\hline 4 & DHAKA BANK LIMITED. & 30 & 632.01 & 21.61 & 7 & 580.09 & 6.15 \\
\hline 5 & DUTCH BANGLA BANK LTD. & 30 & 7893.61 & 818.19 & 7 & 13047.38 & 444.41 \\
\hline 6 & EASTERN BANK LIMITED. & 30 & 1024.64 & 13.32 & 7 & 1220.34 & 18.07 \\
\hline 7 & EXPORT IMPORT BANK OF BD. LTD. & 30 & 377.94 & 8.71 & 7 & 444.67 & 7.84 \\
\hline 8 & IFIC Bank & 30 & 2838.35 & 102.59 & 7 & 3038.58 & 95.57 \\
\hline 9 & ISLAMI BANK BANGLADESH LIMITED. & 30 & 5869.82 & 155.45 & 7 & 7525.34 & 417.18 \\
\hline 10 & Jamuna Bank Ltd. & 30 & 301.95 & 12.32 & 7 & 278.06 & 8.14 \\
\hline 11 & MERCANTILE BANK LIMITED & 30 & 412.44 & 5.14 & 7 & 411.21 & 2.18 \\
\hline 12 & MUTUAL TRUST BANK LTD. & 30 & 534.08 & 22.37 & 7 & 557.22 & 5.61 \\
\hline 13 & NATIONAL BANK LIMITED. & 30 & 1564.49 & 60.62 & 7 & 1512.73 & 18.70 \\
\hline 14 & NCC Bank & 30 & 446.65 & 10.36 & 7 & 459.52 & 7.03 \\
\hline 15 & ONE BANK LIMITED & 30 & 514.17 & 40.98 & 7 & 514.95 & 16.99 \\
\hline 16 & PRIME BANK LTD. & 30 & 883.48 & 11.22 & 7 & 864.43 & 6.40 \\
\hline 17 & PUBALI BANK LIMITD. & 30 & 845.38 & 19.05 & 7 & 843.15 & 13.04 \\
\hline 18 & SHAHJALAL ISLAMI BANK LTD. & 30 & 354.03 & 6.11 & 7 & 345.64 & 4.10 \\
\hline 19 & SOCIAL INVESTMENT BANK LTD. & 30 & 411.15 & 22.69 & 7 & 418.35 & 12.66 \\
\hline 20 & SOUTHEAST BANK LIMITED. & 30 & 539.76 & 14.26 & 7 & 555.48 & 3.81 \\
\hline 21 & STANDARD BANK LIMITED & 30 & 279.87 & 13.72 & 7 & 290.60 & 1.48 \\
\hline 22 & THE CITY BANK LIMITED. & 30 & 619.75 & 9.85 & 7 & 625.92 & 10.30 \\
\hline 23 & The Premier Bank Ltd. & 30 & 267.31 & 6.95 & 7 & 236.40 & 6.11 \\
\hline 24 & Trust Bank Limited & 30 & 670.96 & 48.04 & 7 & 598.69 & 15.20 \\
\hline 25 & UTTARA BANK LIMITED. & 30 & 4741.55 & 162.97 & 7 & 5716.22 & 81.48 \\
\hline
\end{tabular}

Table 3. Hypothesis Test: Independent Groups (t-test, pooled variance)

\begin{tabular}{|r|r|l|}
\hline Mean & Mean & \\
\hline $1,433.216067$ & $1,586.402745$ & mean \\
\hline $1,966.923210$ & $2,522.231583$ & std. dev. \\
\hline 25 & 25 & $\mathrm{n}$ \\
\hline & & \\
\hline & 48 & df \\
\hline & -153.1866786 & difference (Mean - Mean) \\
\hline & $5,115,219.5372294$ & pooled variance \\
\hline & $2,261.6851101$ & pooled std. dev. \\
\hline & 639.7011513 & standard error of difference \\
\hline & 0 & hypothesized difference \\
\hline & & \\
\hline & -0.24 & t \\
\hline & .8118 & p-value (two-tailed) \\
\hline
\end{tabular}




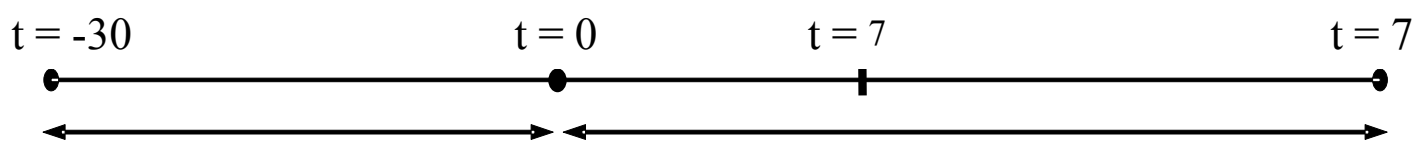

Pre-event Window (30 day)

Post-event window

(7 days after the no price limit date

+7 days before record date)

Figure 1. Pre-event and Post-event Window

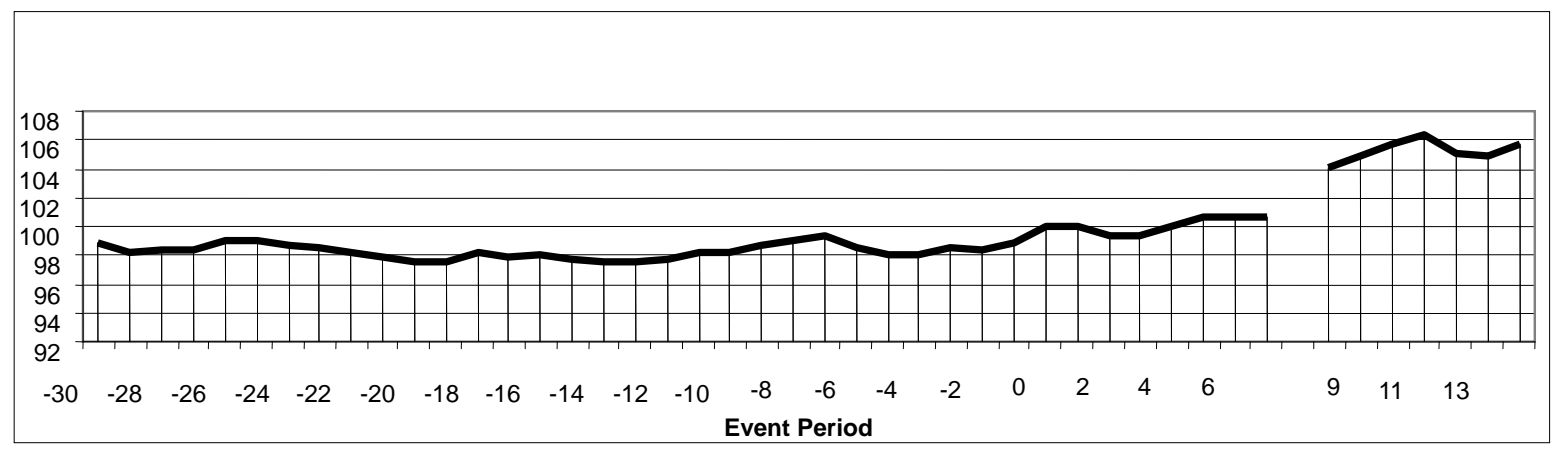

Figure 2. Adjusted Stock Prices in the Time Frame
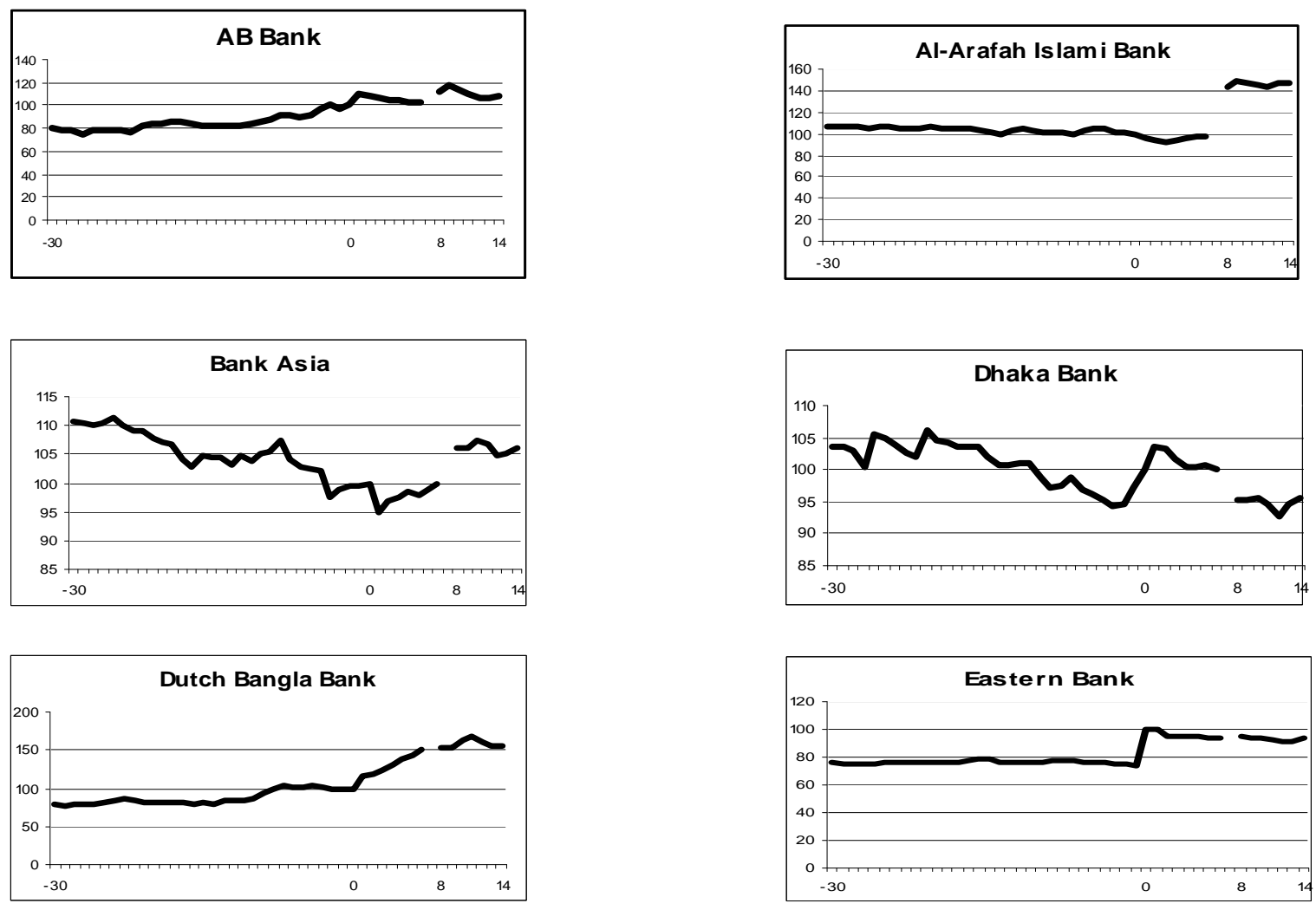

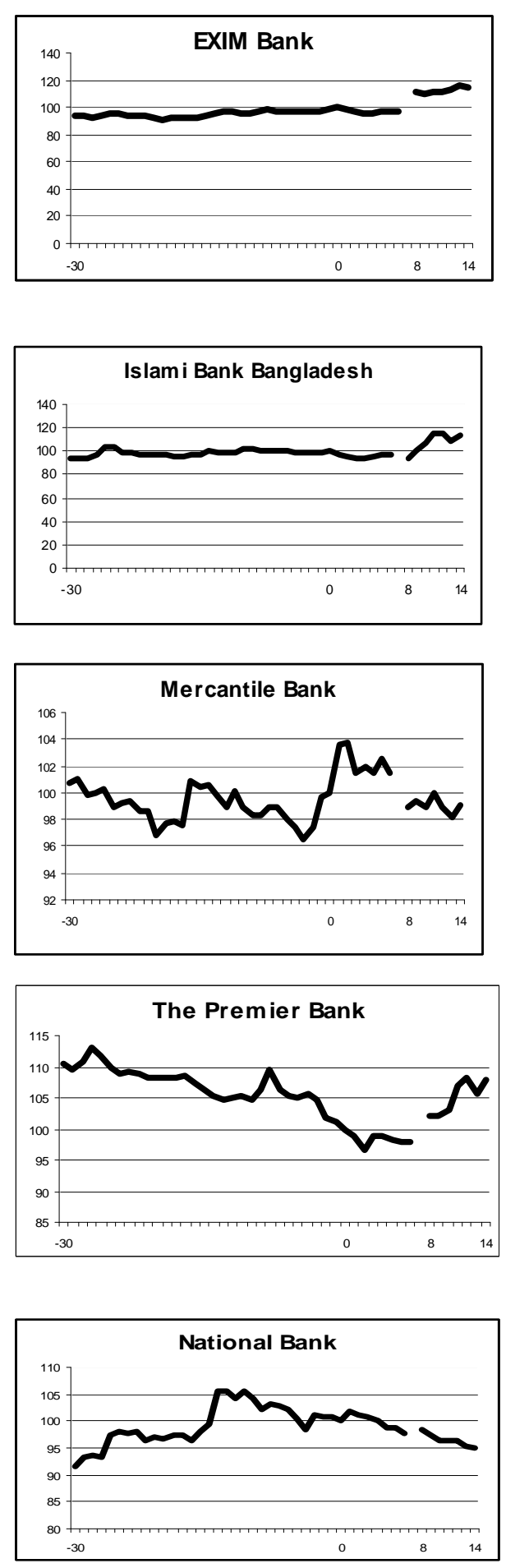
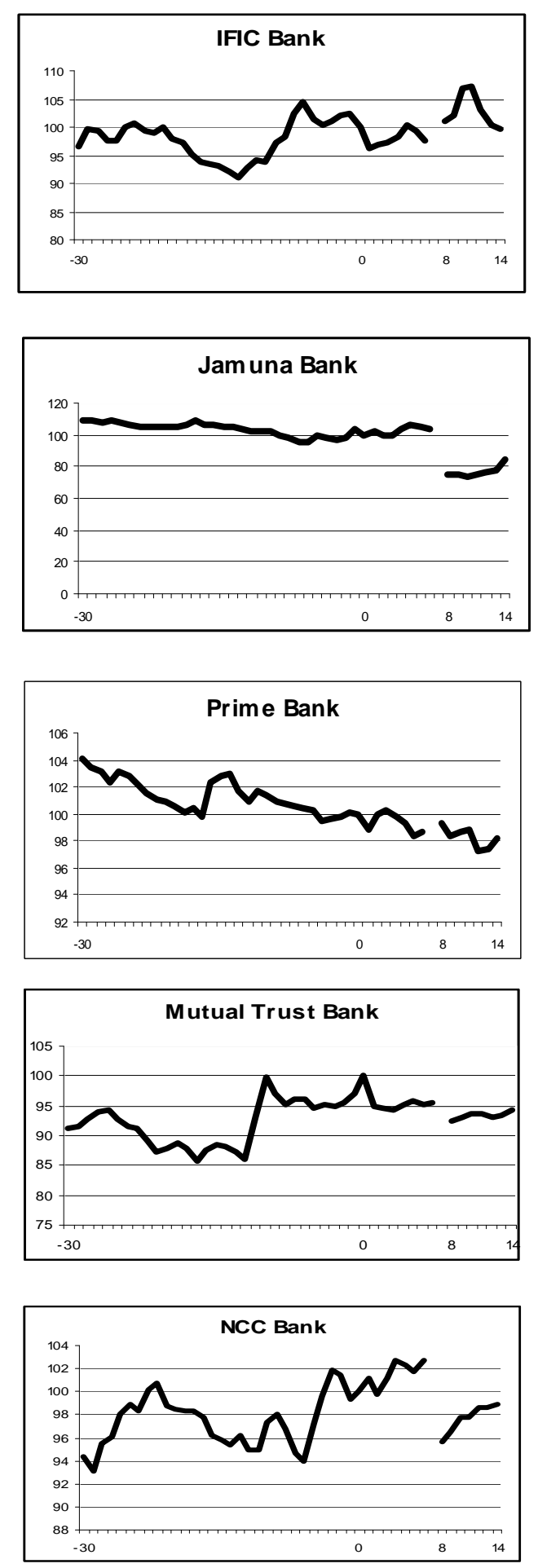

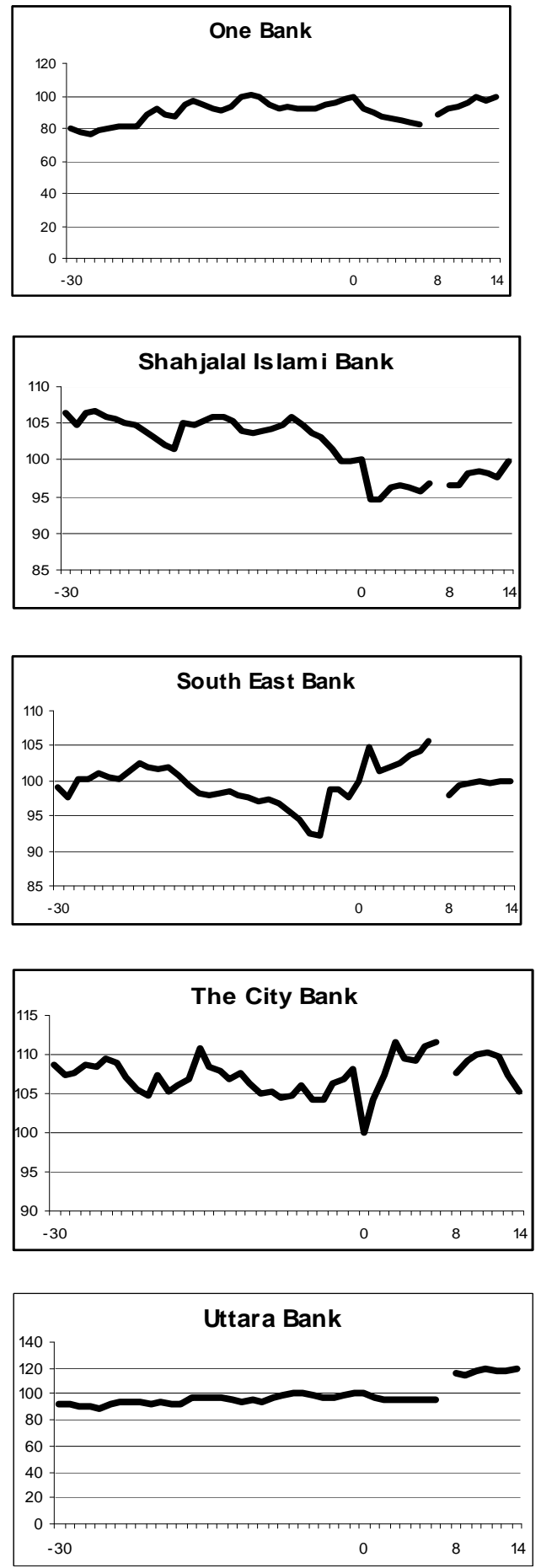

Figure 3. Stock Price Movements of Banks around the Date of Dividend Announcement (Price of the event day is considered as tk.100 and the same is adjusted with the pre-event and post-event window) 